\title{
CARLTONA DOCTRINE IN ADMINISTRATIVE LAW
}

\author{
ARBAB MOHAMMED ABDUL RUB \\ Associate Professor of Law, Department of Private Law, College of Law, \\ University of Bahrain, Kingdom of Bahrain
}

\begin{abstract}
In the Administrative Law of England the Carltona Doctrine is basically concerned with the principle governing the relationship between a Minister and his Civil Servant, and the legal validity of the action taken by a Civil Servant without having previous authorisation to do so.

The said doctrine was evolved by the Court in the famous case of Carltona v. Commissioner of Works ${ }^{1}$. In this case the situation was such that there was no general delegation of power and no specific authorisation in favour of the Secretary to sign a land acquisition order on behalf of the Minister. Therefore, the aggrieved person contended that the acquisition order signed by the civil servant was invalid. But the Court clinging to the conventional principle of Ministerial Responsibility held that the Secretary being in the position of an Alter Ego of the Minister could sign the Acquisition Order and that the Minister had the task of managing the affairs of the Department since he was the person responsible to Parliament.

The Carltona doctrine was evolved in the context of a land acquisition matter, but subsequently in various other cases the question raised was whether the same principle could be applied to the other situations.

In this article, an analysis is given first of the system of Responsibility and Accountability of the Ministers and Civil Servants as it had originated in the system of administrative Law. Then taking note of the gap in the state of law and the new situations the writer asserts that the deficiency in law called for a new principle to fill the gap is highlighted. It was in this background that the doctrine of Carltona emerged in the jurisprudence of English Administrative Law. An analysis is given of the elements of the Doctrine of Carltona. And proceeding further the writer has explored the cases to which the Carltona Doctrine could be applied and the cases to which the doctrine could not be applied.

KEYWORDS: Responsibility and Accountability of Ministers and Civil Servants; Carltona Doctrine \& Application of the Doctrine
\end{abstract}

Received: Sep 21, 2017; Accepted: Oct 10, 2017; Published: Oct 31, 2017; Paper Id.: IJPSLIRDEC20171

\section{INTRODUCTION}

\section{RESPONSIBILITY AND ACCOUNTABILITY OF THE MINISTERS AND CIVIL SERVANTS UNDER THE CONVENTIONAL PRINCIPLES OF ADMINISTRATIVE LAW}

An important aspect of Administrative Law covered by the Carltona Doctrine is the Minister-Civil Servant relationship. This is a matter on which there has been lot of discussion at various levels since several decades adding to the subject matter of Administrative Law.

As far as the system of Responsibility and Accountability of Ministers and Civil Servants is concerned the

\footnotetext{
${ }^{1}$ (1943) 2 All ER 560 (CA) 943
} 
following Developments need to be referred to;

\section{Ministerial Responsibility and Accountability}

The Public Service Committee Report set out the Government view on Ministerial Accountability \& Responsibility thus:

"There is a clear democratic line of accountability which runs from the electorate through MPs to the Government which commands the confidence of a majority of those MPs. in Parliament. The duly constituted government-whatever be its political complexion, is assisted by the Civil Service which is permanent and politically impartial. Hence, Ministers are accountable to Parliament. Hence, Ministers are accountable to Parliament; civil servants are accountable to Ministers. That is the system we have in this country."2

In the light of the Public Service Committee's Report the Parliamentary Committee examined recommended the following as a working definition of Ministerial Responsibility:

"Ministers owe a fundamental duty to account to Parliament. This has, essentially, two meanings.

First, that the executive is obliged to give an account - to provide full information about and explain its actions in Parliament so that they are subject to proper democratic scrutiny.

Second, a Minister's duty to account to Parliament means that the executive is liable to be held to account; it must respond to concerns and criticisms raised in Parliament about its actions because Members of Parliament are democratically elected representatives of the people. A Minister's effective performance of his functions depends on his having the confidence of the House of Commons...."3

The Committee also considered that, as part of ministers' obligation to explain their actions to Parliament, they should make civil servants available to committees. The Government accepted the broad principles set out by the Select Committee, but was concerned that giving civil servants the responsibility to give information to Parliament on their own behalf would muddle their accountability.

On $19^{\text {th }}$ March 1997 the House of Commons had adopted a resolution on Ministerial Accountability in the following terms:

- "Minister have a duty to Parliament to account, and be held accountability for the politics, decisions and actions of their department and next steps agencies;

- It is of paramount importance that Ministers give accurate and truthful information to Parliament, correcting any inadvertent error at the earliest opportunity. Ministers who knowingly mislead Parliament will be expected to offer their resignation to the Prime Minister.

- Ministers should be as open as possible with Parliament, refusing to provide information only when disclosure would not be in the public interest, which should be decided in accordance with relevant statute and the Government's Code of Practice on Access to Government Information (Second Edition, January 1997).

\footnotetext{
${ }^{2}$ Public Service Committee, First Special report of Session 1996-`97, Government Response to the Second Report from the Committee (Session 1995-1996) on Ministerial Accountability and Responsibility, HC 67, Appendix, para 4.

${ }^{3}$ Public Service Committee, Second Report of Session 1995-1996, HC 313-314
} 
- Similarly, Ministers should require civil servants who give evidence before Parliamentary committees on their behalf and under their directions to be as helpful as possible in providing accurate truthful and full informant in accordance with the duties and responsibilities of civil servants as set out in the Civil Service Code (January 1996)."

\section{Civil Servants Accountability}

The doctrine that was enunciated at the time of the Crichel Down affair was that civil servants were accountable to ministers. ${ }^{4}$ Sir David Maxwell Fyfe asserted confidently that:

"The position of the civil servant is that he is wholly and directly responsible to his minister. It is worth stating again that he holds his office "at pleasure" and can be dismissed at any time by the Minister, and that power is nonetheless real because it is seldom used. The only exception relates to a small number of senior posts, like a permanent secretary, deputy secretary or principal finance officer, in which case has been necessary for the Minister to consult the Prime Minister, as he does on appointment."

The view taken by successive governments in UK is that the civil servants are responsible to Ministers, not to Parliament.

\section{THE CONCEPT OF DELEGATED LEGISLATION AND THE RESPONSIBILITY AND ACCOUNTABILITY OF THE MINISTERS \& CIVIL SERVANTS}

A significant feature of the discipline of Administrative Law in England as in many other countries of the world has been the system of Delegated Legislation by which there is delegation of power by the Legislature to the Executive branch of government to make rules for the purpose of securing the aim and objective of the legislation. The delegation of power like this may be not only with regard to the legislative powers but it may be also with regard to the executive and judicial powers. The person or institution receiving such powers under delegated authority may himself delegate the like powers to another person or institution, which practice is known as Sub-Delegation. The sub-delegation also may be with regard to the legislative and executive matters.

Earlier, there was no procedure of Sub-Delegation and the theory that worked on this subject was the theory of 'Delegatus non-potest delegare', i.e., a delegate cannot further delegate his authority. However, in certain situations recognized by the legislature, there could be the procedure of Sub-Delegation.

In the conventional system of delegation and sub-delegation the person or institution delegating the power is known as the principal or delegator of power, and the person receiving the power under delegated authority is known as the 'delegate'. Therefore, when legislative powers are delegated the legislature is the delegator, and when administrative powers are delegated the Executive delegating such powers is known as the delegator.

\section{DEFICIENCY NOTICED IN THE LAW}

While on various aspects of Delegation and Sub-Delegation the rules of conventional administrative law were clear and easy to understand, and were sufficient to answer the questions of legality, there remained an area which was not

\footnotetext{
${ }^{4}$ Library Standard Note, Parliamentary Resolution on Ministerial accountability, House of Commons Library, $24^{\text {th }}$ July 2000.

5 “Individual 1 Ministerial Responsibility - issues, and examples", House of Commons Research Papers, $5^{\text {th }}$ April 2004. 
covered by the rules of Administrative Law This could be because of a situation when the legislative or executive authority was exercised by another person subordinate to the Minister in the same establishment without however any delegation of power to him in specific terms.

In such situations, the question that called for an answer was whether it was proper for the other person to exercise the powers without having prior authorisation from the Minister. The question of propriety that arose was how far a person was justified in exercising the legislative or executive powers without a specific delegation of power in his favour. A more serious question however was whether the action of the subordinate officer was valid in all respects it involved the liability of the Minister in any way. The doctrine of Carltona furnished an answer to these questions.

\section{THE CASE OF CARLTONA}

The Carltona Doctrine was propounded by Lord Greene, MR In the famous case: Carltona Ltd. V. Commissioner of works. The facts of the case and the principle laid down therein were the following:

The plaintiffs, Carltona Ltd., owned a factory which was to be requisitioned. They sought a judicial review of the lawfulness of the order making the requisition, saying that the 1939 Regulations had been implemented not by the Minister as required, but by an official within the Ministry of Works and Planning. They argued that as a holder of a delegated power, the Minister could not himself delegate its use ('delegatus non potest delegare').

Faced with the requisition of their factory by the war-time government, the factory owners raised a judicial review action to challenge the legality of the requisition order. The order had been made under the auspices of the Defence (General) Regulations 1939, which authorised the Commissioners of Works to requisition such land as they deemed necessary in the national interest. The Regulations specified that the Commissioner's powers were exercisable by, inter alia the Minister of Works and Planning. The factory owners sought to argue that the requisition was invalid because the order had not in fact been signed by the minister, but by an official within the Ministry of Works and Planning. In rejecting this contention, the Master of the Rolls, Lord Greene, acknowledged the realities of government in the $20^{\text {th }}$ Century:

The court recognised the inappropriateness of the argument and answered it by holding that in law, as the Northcote-Trevelyan reforms had firmly established in practice, that civil servants acted not on behalf of but in the name of their ministers. The action of the official was not a delegated act; it was the act of the Minister.

A minister could speak through the alter ego of a civil servant in an affidavit. Civil servants are servants of the Crown, not of the ministers who are answerable to Parliament for the departments in which they serve. Where a power or function is conferred on a Minister, in circumstances where, given administrative necessity, Parliament cannot have intended the Minister to exercise the power or function personally, an implied power of delegation (or agency) may be inferred.

Lord Greene MR said: "In the administration of government in this country the functions which are given to ministers (and constitutionally properly given to ministers because they are constitutionally responsible) are functions so multifarious that no minister could ever personally attend to them. To take the example of the present case no doubt there have been thousands of requisitions in this country by individual ministries. It cannot be supposed that this regulation meant that, in each case, the minister in person should direct his mind to the matter. The duties imposed upon ministers and the powers given to ministers are normally exercised under the authority of ministers by responsible officials of the 
department. Public business could not be carried on if that were not the case.

"Constitutionally, the decision of such an official is, of course, the decision of the minister. The minister is responsible. It is he who must answer before Parliament for anything that his officials have done under his authority, and, if for an important matter he selected an official of such junior standing that he could not be expected competently to perform the work; the minister would have to answer for that in Parliament. The whole system of departmental organisation and administration is based on the view that ministers, being responsible to Parliament, will see that important duties are committed to experienced officials. If they do not do that, Parliament is the place where complaint must be made against them. ${ }^{6}$

\section{APPLICATION OF THE CARLTONA DOCTRINE}

The significance of the doctrine lies in the fact that it lets us know the elements of the delicate relationship between the delegator and the delegate and other kindred relations because of which it would be possible to determine the accountability of the persons involved in the functioning of the administrative unit. In the cases that had arisen on the Carltona principle, the concepts of Delegation, Agency and the Alter Ego rule had been examined and the elements of each of them explained by the court.

The reason why we have to know anything about this kind of relationship is that in most of the cases in Administrative Law questions arise as to when a person may be treated as an alter ego and when he may be treated as an agent or a delegate. In other words, the theoretical definitions of delegate, agency and alter ego come in for examination in some context or the other. All these three kinds of relationships are discussed below which can as well help us understand the Scope of the Doctrine.

\section{Delegate}

According to Lord Greene, the Commissioner of Works was not a delegate but an alter ego of the Minister. It was actually the Minister himself who was acting and not the Commissioner. It was also stated by Lord Greene that it was a case of implied authority which the Commissioner was exercising. It was also pointed out that the Minister was still responsible for what the Commissioner had done with regard to the requisition of land.

\section{Alter Ego}

The meaning of the term 'alter ego' is a second self, a perfect substitute or deputy, an inseparable friend, another aspect of one's self. ${ }^{7}$

This term is used in various branches of law in various context but all have the object of pointing to a controlling factor or something which can be held responsible for managing the things. Starting from law of contract the term is used in Company Law, Criminal Law as also Administrative Law. In Company Law of course it is used on a very large canvass to identify the elements who may be held responsible for a certain action taken by the company. In other words, it is used in the context of 'piercing the corporate veil'.

The case of Carltona Ltd. v. Commissioners of Works ${ }^{8}$ and several other cases are authority for the alter ego rule.

\footnotetext{
${ }^{6}$ (1943) 2 All E.R. 560 at 563

${ }^{7}$ Retrieved from Dictionary.com (http:1l.dictionary.com).

${ }^{8}$ Note 4.
} 
In some of the cases the courts have held that besides signing a certain communication, the alter ego may sign the related documents as well such as notices, intimations, memoranda etc.

Agent

In Business organizations the term 'agent' refers to a person who provides a particular service on behalf of another business, person or group. ${ }^{9}$

The term 'agency' refers to relationship between two parties in which one (the agent) is under the control of (is obligated) the other (the principal). The agent is authorized by the principal to perform certain acts, for and on behalf of the principal. The principal is bound by the acts of the agent, performed in carrying out entrusted duties and within the scope of agent's authority. An agency can be created by (1) express agreement, whether oral or written, (2) implication, based on the custom or practice of the trade, or (3) conduct of the principal. Under the legal doctrine of estoppels, the principal is prohibited from denying the existence of properly constituted agency. ${ }^{10}$

The next important case with regard to the application of the doctrine of Carltona is R. (on the application of Bourghass) (Appellants) v. Secretary of State for Justice (Respondent), ${ }^{11}$ decided by the Supreme Court of United Kingdom, on $29^{\text {th }}$ July, 2015 the scope of Carltona principle was examined by the learned Judges in the context of the powers of the Secretary of State and the Governor of the Prison.

The question of law that had arisen in this case was whether the Prison authorities had acted lawfully by subjecting the claimant prisoners to solitary confinement for unbroken periods of several months? Both prisoners were alleged to have been involved --- although, in one of the two cases only indirectly -- in assaults upon another prisoner and to have proselytised. The Court concluded that the claimant's solitary confinement (or segregation) had been lawful for the first 72 hours but unlawful thereafter.

The first question raised by the appellants was whether the authority under rule 45 (2) could lawfully be given by an operational manager, as envisaged by the Prison Service Order (the PSO, 1700) and as occurred in relation to both appellants, given that rule 45 (2) requires authority to be given by the Secretary of State. It was argued on behalf of the Secretary of State that rue 45 (2) permits governors and other senior prison officers to take such decisions. When authorised to do so by the Secretary of State and that such authority has been lawfully granted by the PSO. The Secretary of State's argument was not that a blanket authorisation has been granted by the Secretary of State ab ante. The argument rather was that the decision of the governor or the operational manager was the decision of the Secretary of State, by virtue of the operation of the Carltona principle. Alternatively, it was argued that the words "the Secretary of State" in rule 45 (2) should as a matter of construction be interpreted as including prison governors and other senior officers.

The Supreme Court's conclusion was reached principally on the basis of statutory construction and the application of the ultra vires principle, the question simply being whether the relevant legislation authorised solitary confinement beyond 72 hours without the involvement of the Secretary of State.

Lord Neuberger, President in his judgment observed,

\footnotetext{
${ }^{9}$ Retrieved from Dictionary.com. (http: II. Dictionary.com.)

${ }^{10}$ Retrieved from http://www.businessdictionary.com/definition/agency

11 2-15_UKSC 54
} 
"As in the cases of Hague ${ }^{12}$ and Somervlle ${ }^{13}$ it can in my opinion be inferred that rule 45 (2) is intended to provide a safeguard for the prisoner; a safeguard which can only be meaningful if the function created by article 45 (2) is performed by an official from outside the prison. It makes sense that the governor should be able to act at his own hand initially, since decisions to remove a prisoner from association with other prisoners may need to be taken urgently. It also makes sense that the governor should be able, under rule 45 (3) to arrange for the prisoner's resumption of association with other prisoners at any time, and, in particular, in response to any medical recommendation. Rule 45 (2) however ensures that segregation does not continue for a prolonged period without the matter being considered not only by the governor but also by officials independent of the management of the prison. If, as counsel, submitted rule 45 (2) was not intended to provide a safeguard, then the requirement to obtain the authority of the Secretary of State, before serration can lawfully continue for more than 72 hours, would lack any rationale."

In an identical case involving the scope of Rule 43 of the Prison Service Order Lord Justice Taylor in the case: R. V. Deputy Governor of Parkhurst Exp. Hague ${ }^{14}$ addressed an argument that the Secretary of State possessed a residual power to initiate segregation under rule 43 . He observed at p. 107:,

"Whether or not the Secretary of State retains an overall power to segregate a prisoner, he cannot, in my judgment, exercise it under rule 43 because that rule gives powers specifically to the governor. Rule 43 (2) provides for authority to be given to the governor to segregate for more than 24 hours by either a visitor or the Secretary of State. But that authority is merely clothing for the governor. The decision 'under this rule' is still his. I do not accept, therefore that the Secretary of State can act under rule 43 to initiate segregation."

\section{CONCLUSIONS}

From the above discussion it may be inferred that the Carltona Doctrine was evolved by the English Court to meet a particular situation. It had the objective of strengthening the system of administration based on the principle of Ministerial Responsibility.

A comment of the writer of this article is that the doctrine was a salutary mode of allowing the work of the department to go on. It has rightly based its verdict on the principle of accountability; the Minister who is accountable to Parliament can allow the work to go on the assumption that the Secretary could be trusted with the responsibility

Thanks to the understanding which the Minster had with his Secretary the work could go on. But serious problems would arise if there is lack of confidence; the lack of authorisation would vitiate the work done by the Secretary and when the matter is taken to the court of law the administrative action of the department would fail.

\section{REFERENCES}

1. Prof. Wade, 'Administrative Law', Oxford 1967.

2. Ivor Jennings, "The Law and the Constitution", University of London Press, 1959.

3. K. C. Davis, “Administrative Law as the law concerning the powers and procedures of administrative agencies':

4. Jain and Jain, Administrative Law". LexisNexis Butterworths Wadhwa 2010.

\footnotetext{
${ }^{12}$ R. v. Deputy Governor of Parkhurst Prison, ex parte Hague (1992) 1 AC 58

${ }^{13}$ Somerville v. Scottish Ministers, (2007) UKHL 44

${ }^{14}$ (1992) AC 58
} 
5. Griffith and Street, 'Principles of Administrative Law', Pitman, 1963

6. A. Bradley and K. Ewing, 'Constitutional and Administrative Law', London 1997.

7. K. C. Davis, 'Discretionary Justice: A Preliminary Inquiry', III. Univ. Of Illinois.

8. De Smith, Woolf and Jowell, 'Judicial Review of Administrative Action' (5 ${ }^{\text {th }}$ Edn.). Sweet \& Maxwell, 1995.

9. Freedland, 'The Rule against Delegation and the Carltona Doctrine in an Agency context' (1996) Public Law 19.

10. Lanham, 'Delegation and the Alter Ego Principle' (1984) 100 Law Quarterly Review, 587 